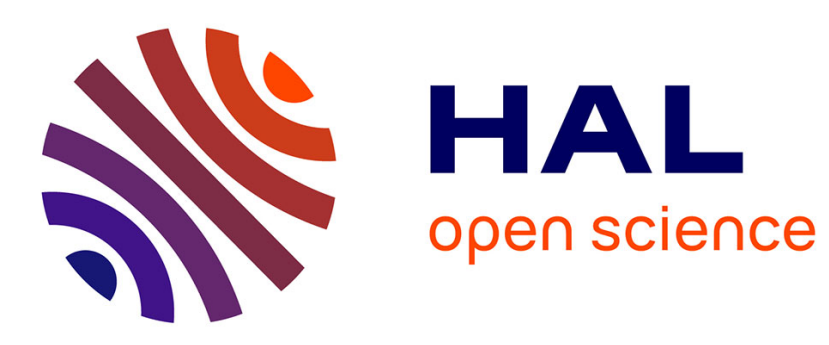

\title{
Dimensions of proximity and knowledge bases Innovation between spatial and non-spatial factors
}

\author{
Jannika Mattes
}

\section{To cite this version:}

Jannika Mattes. Dimensions of proximity and knowledge bases Innovation between spatial and nonspatial factors. Regional Studies, 2011, pp.1. 10.1080/00343404.2011.552493 . hal-00694718

\section{HAL Id: hal-00694718 \\ https://hal.science/hal-00694718}

Submitted on 6 May 2012

HAL is a multi-disciplinary open access archive for the deposit and dissemination of scientific research documents, whether they are published or not. The documents may come from teaching and research institutions in France or abroad, or from public or private research centers.
L'archive ouverte pluridisciplinaire HAL, est destinée au dépôt et à la diffusion de documents scientifiques de niveau recherche, publiés ou non, émanant des établissements d'enseignement et de recherche français ou étrangers, des laboratoires publics ou privés. 


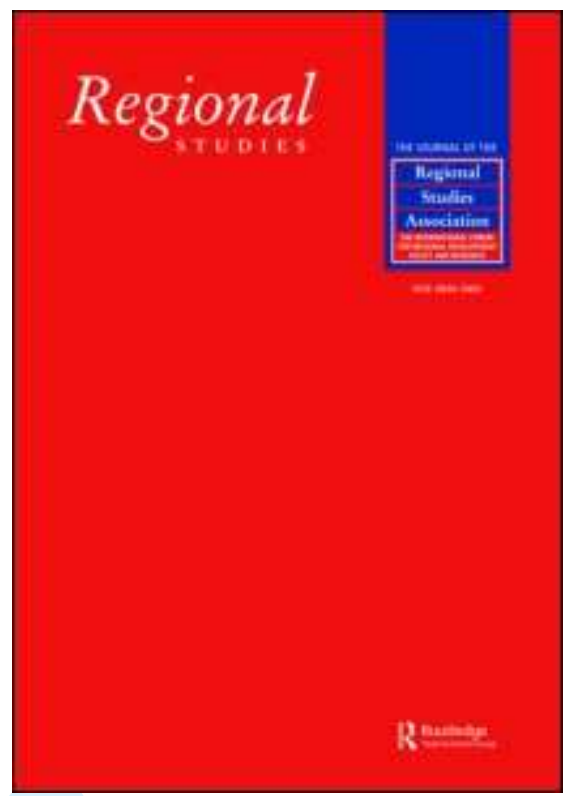

Dimensions of proximity and knowledge bases Innovation between spatial and non-spatial factors

\begin{tabular}{|r|l|}
\hline Journal: & Regional Studies \\
\hline Manuscript ID: & CRES-2009-0147.R2 \\
\hline Manuscript Type: & Main Section \\
\hline JEL codes: & $\begin{array}{l}\text { O31 - Innovation and Invention: Processes and Incentives < O3 - } \\
\text { Technological Change|Research and Development < O - Economic } \\
\text { Development, Technological Change, and Growth, O32 - } \\
\text { Technological Change|Research and Development < O - Economic } \\
\text { Development, Technological Change, and Growth, O33 - } \\
\text { Technological Change: Choices and Consequences|Diffusion } \\
\text { Processes < O3 - Technological Change|Research and Development } \\
<\text { O - Economic Development, Technological Change, and Growth }\end{array}$ \\
\hline \hline Keywords: & $\begin{array}{l}\text { proximity, knowledge base, learning, learning regions, geographic } \\
\text { proximity }\end{array}$ \\
\hline \hline
\end{tabular}

\section{SCHOLARONE" Manuscripts}


(Cris: please note that the author provided only the German title for the abstract; she preferred to have the translations done by us but she did provide the title for the German abstract)

\section{Dimensions of proximity and knowledge bases \\ Innovation between spatial and non-spatial factors}

Jannika Mattes, CETRO, University of Oldenburg, Ammerländer Heerstr. 114-118, 26129 Oldenburg, Germany, jannika.mattes@uni-oldenburg.de

(Received May 2009: in revised form December 2010) 


\begin{abstract}
Innovations face the challenge of integrating knowledge from heterogeneous sources by establishing an appropriate level of proximity. Proximity is thereby not a purely spatial phenomenon, but also includes organisational, institutional, social and cognitive dimensions. Geographical and social proximity are thereby auxiliary factors, whereas organisational, institutional and cognitive proximity act as critical enablers for learning. These dimensions can be connected to synthetic, analytical and symbolic knowledge bases. They thereby trigger a dynamic trade-off between various forms of proximity, whereby the proximity form varies depending on the underlying knowledge base. Innovation hence is a complex combination of spatial and non-spatial factors.
\end{abstract}

Dimensionen von Nähe und Wissensbasen. Innovation zwischen räumlichen und nicht-räumlichen Faktoren Keywords

Proximity, knowledge base, learning, learning regions, geographic proximity.

\title{
JEL codes
}

O31 - Innovation and Invention: Processes and Incentives < O3 - Technological Change|Research and Development $<0$ - Economic Development, Technological Change, and Growth,

032 - Management of Technological Innovation and R\&D $<03$ - Technological Change|Research and Development $<0$ - Economic Development, Technological Change, and Growth,

O33 - Technological Change: Choices and Consequences|Diffusion Processes < 03 - Technological

Change|Research and Development $<0$ - Economic Development, Technological Change, and Growth 


\section{Introduction}

Learning and innovation are closely connected to heterogeneity. The mere definition of innovation as the combination of existing knowledge or the creation of something new (LINCOLN and GUBA, 1987; EDQUIST, $2001^{1}$ ) shows that innovation goes beyond existing structures and is directly linked to the combination of heterogeneous knowledge (PAVITT, 2005). At the same time, learning is a difficult matter. The transfer of knowledge deeply relies upon proximity, as the assimilation of the exchanged knowledge is not possible at all without it.

Innovations involve the challenge of enabling renewal based on heterogeneity and facilitating the integration of knowledge through proximity. $^{2}$ Knowledge is, thereby, a complicated and not a homogeneous phenomenon. Many authors have pointed to the importance of geographical proximity in achieving an integration of diverse knowledge (cf. e.g. AMIN, 1999; AUDRETSCH, 2000; BATHELT et al., 2004; ENRIGHT, 1998), but its sources are often dispersed as innovation projects also involve heterogeneous internal and external actors from different places and backgrounds (BECHKY, 2003). The ability to innovate turns into an "ability to integrate, build, and reconfigure internal and external competences to address rapidly changing environments" (TEECE et al., 1997, p. 516), i.e. the ability to manage heterogeneous cooperation. Organisations hence have to find different ways to enable the involved heterogeneous actors to innovate.

The differentiation between various dimensions of proximity serves as an interesting starting point for understanding better how innovation can be organised. Proximity has frequently been treated as a purely geographical concept, although organisational, institutional, social and cognitive aspects play an equally important role (BOSCHMA, 2005). This article will demonstrate that geographical proximity may be important, but is simultaneously influenced by other dimensions of proximity which complement and substitute it. The first objective of this paper is hence to show how these forms of proximity fulfil different roles, in that cognitive, organisational and institutional proximity provide the foundation for collaboration, whereas geographical and social factors act as reinforcing dimensions. This shifts the problem from defining the appropriate level of proximity to arranging the dimensions of proximity. Without proclaiming the "death of geography" as such (MORGAN, 2004), a multifaceted perspective on proximity is indispensable in 
order to abolish the geographical bias in the explication of innovativeness and instead fully grasp both the spatial and non-spatial dynamics inherent in innovation.

Although these proximity aspects are useful for the analysis of learning and innovation, the debate on proximity (BOSCHMA, 2005; BOSCHMA and FRENKEN, 2010; WETERINGS and BOSCHMA, 2009) has not explicitly taken into account the complexity inherent in the use and transfer of knowledge in different contexts. Instead, knowledge has been treated as a homogeneous concept. However, knowledge is a multifaceted concept which assumes a whole variety of shapes in different situations. In order to grasp the complexity inherent in knowledge transfer, the second objective of this article is to connect the five forms of proximity to synthetic, analytical and symbolic knowledge bases (ASHEIM and COENEN, 2005; MOODYSSON et al., 2008). These knowledge bases mirror the availability and relevance of types of knowledge in a certain geographical or sectoral setting.

By connecting these two strands of literature, the article seeks to find proximity configurations in knowledge bases, asks for the relationships between these and for spatial implications. Constellations of proximity dimensions are neither universal nor fully industry-specific, but appear as a dynamic process of adaptation, substituting each other in innovation processes. In this manner, organising innovation involves a constant trade-off between various forms of proximity. This article thus contributes to the preciseness and applicability of the concept. From a geographical perspective, a stricter differentiation between spatial and non-spatial factors contributes to a better understanding of the dynamics occurring in innovation projects.

In order to further the understanding of the relationship between proximity and knowledge bases, this article will proceed as follows. Section 2 addresses how innovation draws upon both proximity and heterogeneity and illustrates the importance of both. This will help to derive the necessity to dig deeper into this subject and to sketch possible ways of establishing a balance. Possible solutions are not only rooted in the degree of proximity, but also in the involved dimensions of proximity. Above all, proximity cannot be looked at as a purely spatial problem. Section 3 differentiates between five dimensions of proximity and classifies them as strategic, normative, cognitive and supporting categories. The importance 
of the proximity types cannot be understood independently from the involved form of knowledge. By transferring these dimensions of proximity to differing knowledge bases - synthetic, analytical and symbolic ones - section 4 sketches expected patterns of proximity which inherently mirror sectoral differences. The proposed trade-off between various types of proximity shows that establishing a balance between proximity and heterogeneity involves a dynamic, constant adaptation even within a single project. The paper finishes with a brief conclusion which outlines the need for further research in this field (section 5).

\section{Heterogeneity and proximity - two sides of the same coin}

Heterogeneity, as can easily be derived from its close connection to innovativeness, carries important advantages for innovation projects. In a way, heterogeneity in a project is always reliant upon some form of cooperation. An isolated person cannot be heterogeneous, as diversity derives from a combination of diverse actors along with their respective skills and competences. In this way, cooperation can be a source of innovation (MUDAMBI et al., 2007) as it allows the combination of different knowledge sources and helps to gain access to new knowledge. Furthermore, the interaction between heterogeneous actors triggers creativity and thus allows for the development of new ideas which could not have emerged in isolation. Hence, heterogeneity, or variety, is essential for any innovation project. In order to be innovative, especially internationally oriented projects rely upon the input of extra-corporate cooperation partners and the resulting learning chances (CANTWELL, 2005). The cooperation between heterogeneous partners allows for the drawing upon additional expertise (BURT, 1992) and the accessing of additional knowledge (ZHANG et al., 2007). This helps to combine different competences and to integrate explorative and exploitative learning into the innovation project (MARCH, 1991; cf. also CALANTONE and STANKO, 2007; ROTHAERMEL and DEEDS, 2004). At the same time, cooperation breaks up established paths (WIESENTHAL, 1995; GERYBADZE, 2004; RAMMERT, 1988) and thereby avoids getting trapped in lock-in situations (GRABHER, 1993). So, the inherent heterogeneity seems to be beneficial for innovation (POWELL and GRODAL, 2005). Nonetheless, this is only one side of the coin. Heterogeneity brings with it a high level of complexity, which can cause coordination problems (STRÜBING 2004). Communication is thus difficult (ANCONA and CALDWELL, 1992), conflicts emerge (HOERING et al., 2001), and groups break up easily 
(EGELHOFF, 2005). This does not only refer to scheduling, team work and related issues, but especially to the difficulty in exchanging knowledge between various project participants. Knowledge is always contextrelated and cannot simply be transferred seamlessly like a parcel to other actors (BOSCHMA, 2005; GLÄSER et al., 2004). Thus, if learning among actors is to take place in a project, a certain degree of proximity is necessary to establish a boundary object (STAR and GRIESEMER, 1989). This explains why proximity is just as important as heterogeneity. Innovation is based on trust and solidarity (POWELL, 1990; WURCHE, 1994), even if a contract acts as additional safeguard (ZELLER, 2002). Proximity, however, is based on similarities and a shared understanding. Hence, it relies on homogeneity with regard to at least one characteristic and is, in this way, opposed to heterogeneity.

This illustrates that a balance between proximity and heterogeneity is a major challenge of innovation. As can be seen, too much heterogeneity on the one hand and too much proximity on the other can be harmful (BOSCHMA, 2005; BOSCHMA and FRENKEN, 2010). The decision about whom to involve in an innovation project is consequently a delicate balancing act (POWELL and GRODAL, 2005). In dealing with these two prerequisites, two important issues have to be considered. First of all, companies will seek to find the adequate degree of proximity - and hence also of heterogeneity. Obviously, there is no perfect solution as it is impossible to maximise both heterogeneity and proximity at the same time. Thus, secondly, establishing the appropriate degree of proximity turns into a question of different dimensions of proximity (BOSCHMA, 2005). The balancing act between proximity and distance is not a purely spatial one. Although many contributions have pointed to the importance of the geographical dimension of learning, the spatial focus does not provide a full picture. Proximity is a multifaceted phenomenon, and one can differentiate between its cognitive, strategic and normative aspects as well as social and geographical proximity which act as reinforcing dimensions. The following section will address this challenge in more detail.

\section{Proximity - a multifaceted phenomenon}

Proximity has often been analysed as a geographic phenomenon (cf. e.g. AMIN, 1999; AUDRETSCH, 2000; BATHELT et al., 2004; ENRIGHT, 1998). This can be justified in several ways, especially since geographic proximity certainly plays a major role in the transmission of knowledge (FRITSCH and FRANKE, 2004). 
Innovation is thus described as a highly localised phenomenon (KILDUFF, 2005) for which geographical proximity matters (LOVERIDGE, 2007; GERTLER, 2008).

However, a closer look at geographic proximity shows that it has often been used as a catch-all phrase. Of course, the geographical arrangement of activities is important, and short distances between actors enable a smoother and less complicated interaction. For example, RODRÍGUEZ-POSE and ZADEMACH (2006) show convincingly that geographic distance plays a major role in decisions about mergers and acquisitions. Nonetheless, they do not separate spatial from other factors, such as the institutional setting. In a strict sense, their results can only be interpreted as proof that proximity is still important. What they do not enlighten is which type of proximity is crucial. In this sense, the mechanisms that make locations important have not been explained satisfactorily (GIULIANI, 2007). Also, the definition of the terms "spatial" or "geographical" often remains fuzzy.

Also, studies with a geographical orientation tend to focus exclusively on external embeddedness, i.e. on connections between a company and its regional surroundings. Thereby, they neglect firm-specific and other important characteristics (GIULIANI, 2007, GIULIANI, 2008). For example, geographical proximity cannot explain connections to partners in distant locations (GERTLER, 2008), and learning often takes place in a combination of both geographically close and distant settings (BATHELT et al., 2004). Relational networks thereby act in a complementary fashion towards purely geographical ones (MAGGIONI et al., 2007). This is why the context of learning should be taken into account in a more structured way to enhance our understanding of the involved spatial and non-spatial dynamics (STORPER, 2009³; cf. also ZANFEI, 2000). ${ }^{4}$

The picture gets even more complicated when companies are active in several countries. Heterogeneity hereby derives from both internal and external cooperation. First, various subsidiaries are situated in different contexts and bring together actors with a diverse educational and cultural background (MORGAN, 2001; ZANFEI, 2000), which creates an internal heterogeneity of the knowledge base (BLACKLER et al., 2000; GRANT, 1996; HISLOP, 2003). The relevant knowledge for innovation projects is thus not concentrated in a single location, but increasingly spread out across the world (AMBOS, 2005; DOZ et al., 
2001; HEIKKINEN and TÄHTINEN, 2006). This results in an augmented need to find new ways of coordination (BECKER-RITTERSPACH, 2006). At the same time, internationally active companies can enter external cooperation in any of these locations, which again increases the level of complexity involved (cf. e.g. INKPEN and TSANG, 2005; GHOSHAL and WESTNEY, 2005; CHILD and HEAVENS, 2007; MARSH and STOCK, 2006). Taking this into account, geographical proximity cannot be the only way in which heterogeneous actors are held together. Learning is a far more complex phenomenon which takes place as a socio-spatial process (SAYER, 1985). In this broader view, space turns into a relational issue and ceases to be a purely geographical concept. It is instead significantly constituted via social and contextual factors (GEPPERT and CLARK, 2003; MORGAN, 2004; SAYER, 1982, 1992). The understanding of space as a social rather than a physical phenomenon (SAYER, 2000) makes it necessary to open up the black box of geographic proximity and distinguish more precisely between the different types of proximity involved (cf. also HESS, 2004). With this aim in mind, BOSCHMA (2005) distinguishes between five dimensions of proximity: geographical proximity, institutional proximity, organisational proximity, cognitive proximity and social proximity. The following section will briefly address each of these five forms in order to show how they differ from each other and also how they interrelate.

Knowledge transfer can hence be the result of various types of proximity. ${ }^{5}$ BOSCHMA $(2005, p .71)$ puts it the following way: "Organizational, social, institutional and geographical proximity may (...) provide solutions to this fundamental problem of coordination. In theory, geographical proximity, combined with some level of cognitive proximity, is sufficient for interactive learning to take place. Other forms of proximity may, however, act as substitute for geographical proximity." Geographical proximity is thus neither a necessary nor a sufficient condition for enabling learning (BOSCHMA, 2005), i.e. its existence does not at all guarantee that learning does in fact take place. Instead, learning can occur without geographical proximity - and in turn, more factors are to be considered than merely spatial ones.

Also, knowledge spillovers are not automatic (BOSCHMA and IAMMARINO, 2009; FRENKEN et al., 2007), no matter how close geographic proximity may be. To have two people sitting in the same room does not necessarily imply that learning will take place. The involved individuals need not look at each other, let alone talk to one another. The transfer of knowledge, thus, always includes some intention to 
interact, to learn, to share and absorb information. The first and most essential condition is that the actors who are involved in learning are able to understand each other, i.e. use a "common interpretative scheme" (MARKUSEN, 1996). The cognitive dimension of learning hence lies at the very core of the learning process. It refers to the knowledge all the actors involved held before the learning process began. If the cognitive distance is too large, the actors involved will not understand each other and will not be able to interpret and assimilate the transferred knowledge (NOOTEBOOM, 1999). At the same time, if it is too small, cooperation does not grant access to new knowledge. This is why the optimal level of cognitive distance is often represented as an inverted U-shaped curve (NOOTEBOOM et al., 2007; BOSCHMA, 2005), and there is a constant strive to achieve an appropriate level of cognitive distance (GRABHER, 2004). Evidently, without a balanced level of cognitive distance, learning cannot occur at all. Hence, the cognitive dimension is more important than the spatial one (MOODYSSON et al., 2008), and it can be regarded as a necessary condition for learning.

Once the cognitive dimension is set up, in a way which provides a suitable basis for learning, two other dimensions of proximity enter the game. The first is strategic, i.e. a control-related dimension (organisational proximity) and the second is a normative dimension (institutional proximity). BOSCHMA (2005, p. 65) defines organisational proximity as "the extent to which relations are shared in an organizational arrangement". In a narrower understanding, this refers to the degree of internalisation, i.e. a high organisational proximity means that the participants follow similar organisational logics or even belong to the same company group. ${ }^{6}$ In this way, organisational proximity is closely related to a single control instance which is in charge of all the relevant activities. With all the related tasks being carried out within a single organisation, the company prevents external actors from accessing their knowledge and as a result gaining insight into any of their innovative activities (BENDER, 2004). This implies that the organisation maintains its ownership rights and maximises its level of control (ZELLER, 2002; BECKER and KNUDSEN, 2006). As competition can also arise between subsidiaries, organisational proximity is even higher within one subsidiary than in the company group as a whole. ${ }^{7}$ Its effects are thereby ambiguous. While it facilitates coordination, organisational proximity causes cuts in a firm's flexibility and can thereby hinder the emergence of innovation (BOSCHMA, 2005). Achieving an appropriate level of organisational proximity 
is thus a very difficult subject for internationally oriented companies (POWELL and GRODAL, 2005), as it may be necessary to draw upon additional knowledge and incorporate external partners in order to be innovative. At the same time, protecting the company's knowledge base is one of the most important keys to competitiveness.

The normative dimension of proximity refers to institutional properties. Hard institutional factors like laws and rules are thereby equally important as soft ones, i.e. norms, values and routines. All together, they form the socio-cultural, economic and political framework in which the actors are embedded (BOSCHMA, 2005). In this manner, institutional proximity is a complex combination of macro-level factors (XU and SHENKAR, 2002) which simultaneously enable and restrain learning. ${ }^{8}$ In many instances, the importance of geographical co-location resides mainly in the context-specificity of knowledge (GERTLER, 2003), i.e. institutional proximity. ASHEIM and COENEN (2005) describe how regional agglomeration relies on institutional factors. In this sense, as many institutions are defined or valid in a specific regional setting, institutional proximity is often mistaken to be geographical. ${ }^{9}$ More precisely, geographical proximity implies co-location, and institutional proximity refers to coherence in regard to laws and values. In fact, most arguments involved in the debate on regional innovation systems (RIS) focus on how institutional settings create learning opportunities (COOKE, 2001; HISLOP, 2003), which shows again how the term "spatial" proximity can be misleading. A closer look at this debate shows that it is mainly a discussion about institutions which accommodate local firms, i.e. about institutional proximity.

Besides these three main dimensions of proximity, the cognitive, organisational and institutional ones, social and geographical proximity act as auxiliary categories. These are not focussing so closely on either control, framework or cognition, but act as intermediary variables fostering and reinforcing the creation of other types of proximity whilst, simultaneously, providing a degree of proximity in themselves. This does not mean that they are less important, but implies that they can only constitute innovationrelevant bonding mechanisms if they accompany cognitive, organisational or institutional proximity forms.

In this manner, social and geographical proximity act as accompanying variables to the three main dimensions. Social proximity comes about as a result of shared personality characteristics, personal 
interaction and a sense of familiarity between individual actors. In its mode of creating mutuality among actors, it is closely related to institutional proximity, but takes place at the micro-level and occurs in the form of friendship or kinship or also based on past interactions. More than any of the other dimensions of proximity, social proximity relies on trust and in this manner encourages actors to engage in communication (BOSCHMA, 2005). The simple sharing of characteristics like gender or race can intensify the bonds between actors in a network (IBARRA et al., 2005). This is particularly evident in communities of practice or epistemic communities. ${ }^{10}$ Even stronger, friendships and other informal relationships are important door-openers to new jobs (and thus towards re-connecting actors who may learn from each other) (GRABHER and IBERT, 2006), and socially well-connected individuals act as gatekeepers linking different research groups (BRESCHI and CATALINI, 2007). These examples show how powerful social proximity can be. ${ }^{11}$

This inherent characteristic for encouraging communication and facilitating interaction is also exactly what geographical proximity provides. In a strict sense of the term, physical geographical proximity is defined as co-location of the involved actors. In such a local context, it is easy to establish contacts with potential cooperation partners and to exchange knowledge without major effort (cf. also MORGAN, 2004). Casual and unintended meetings, overhearing conversations and constant exposure to a vivid 'industrial atmosphere' (MARSHALL, 1919; ASHEIM, 2000) result in 'buzz'12, continuous knowledge spillovers (MARSHALL, 1979 [1890]; BATHELT et al., 2004; STORPER and VENABLES, 2004) and 'unintended interdependencies' (STORPER, 1997). ${ }^{13}$ This shows that "soft" factors, i.e. untouchable, tacit elements, seem to be more crucial in connection to geographic proximity, whereas most of the other factors can be traced back to one of the other types of proximity. Hereby, geographical proximity is also regarded as a means of creating trust (MASKELL and MALMBERG, 1999; MORGAN, 2004), i.e. as a mechanism fostering social proximity. In its purest sense, geographical proximity is a mechanism that helps to establish additional proximity which might also have been created without the spatial component, but not as easily (cf. also GERTLER, 2008 ${ }^{14}$ ). In this sense, geographical proximity carries strong relational elements (MORGAN, 2004; SAYER, 2000). Its auxiliary character can hence be traced back to the relational nature of 
space (cf. also YEUNG, 2005; BATHELT and GLÜCKLER, 2003). As space is not purely geographical, the bonding elements are likewise more varied. ${ }^{15}$

Above all, as we can see, geographic proximity facilitates face-to-face interaction and may in turn favour innovation (ASHEIM et al., 2007). However, the need to interact does not necessarily result in agglomerations, but can also take place as a temporary co-location. Travelling (and being in the same place on a temporary basis) acts as a substitute to traditional clustering in many cases. Similarly as the continuous allocation of all actors in the same place, temporary co-location can foster the emergence of common frames of thought, of personal bonds and of mutual understanding, and in this way opens up novel learning opportunities (MASKELL et al., 2006; TORRE, 2008).

The differentiation between the five types of proximity, in this manner, leads back to the initial question on the role of spatial proximity. It can be stated that proximity is a phenomenon that goes far beyond the geographical dimension. Important proximity elements can also be traced back to cognitive, institutional, organisational and social factors. In order to fully understand spatial implications of innovation, it is indispensable to take these non-spatial factors into account.

It has to be noted that the different types of proximity are closely interrelated (cf. also KNOBEN and OERLEMANS, 2006). Although geographical proximity may not be decisive in itself, it carries with it a reinforcing power which triggers the other types of proximity (BOSCHMA, 2005). In essence, it acts as a facilitator for the creation of further proximities, and it is generally an enabler for closer interaction and interconnections. A particularly close interrelation can be observed between institutional and geographical proximity (BOSCHMA, 2005; GERTLER, 2003). In a similar way, social proximity is closely interconnected with all the other types of proximity. More than paving the path for the other forms, it is encouraged by them, occurring as a side-effect and as a result of proximities in the other dimensions. The social effects in turn reinforce the initial proximity forms, too, which can lead to a spiral of reinforcing dynamics. Above all, social proximity often represents the macro-level institutional proximity on the micro level. 
When considering these interrelations, it is crucial to note that the terminology is often used in a fuzzy and confusing way. For example, IBARRA (2005) describes social preferences towards relatives as a cognitive phenomenon - with the definition introduced above, this is clearly social proximity. Nevertheless, the tension inherent in all these types of proximity is, surprisingly, very similar. Too much proximity results in lock-in effects and reduces learning potentials. Too little proximity leads to difficulties in assimilating the exchanged knowledge and entails a lack of learning capacity.

In conclusion, the introduction of these five proximity forms and their classification in various categories displays that the discussion on proximity has so far treated knowledge as a homogeneous concept and has failed to ask questions about the factors which may influence the relationship between and the importance of various forms of proximity. In this sense the five identified forms of proximity are only the first step. The second step is to dig deeper into their interdependence with knowledge. The presented debate treats knowledge as a coherent whole, and it neglects the vast amount of shades and differentiations which occur between various types of knowledge and between contexts in which knowledge is being used. The ways of dealing with the dichotomy between proximity and heterogeneity differ between these suggested types of proximity, which makes an array of proximity combinations available to innovation projects. The next section differentiates between different knowledge bases (MOODYSSON et al., 2008; ASHEIM et al., 2007). This helps to explain which types of proximity are important for which types of knowledge and, hence, for which sectors as it disentangles the spatial and non-spatial characteristics of the various constellations.

\section{Knowledge bases and proximity}

The differentiation between different dimensions of proximity has so far been a conceptual one. The understanding of proximities can, thus, be enhanced by linking it to different types of knowledge. In such a view, knowledge cannot be regarded as a homogeneous entity, but has to be taken into account as a manifold, complicated and multi-faceted construct. Instead of treating it as a catch-all term, explicating the link between the identified proximity types and the different types of knowledge can foster a deeper and 
more differentiated understanding of both. This challenge is at the core of this article and will now be addressed.

Traditionally, the different degrees to which proximity matters in knowledge transfers has been linked to the nature of the involved knowledge, i.e. the classical distinction between tacit and explicit knowledge (POLANYI, 1978; cf. also ASHEIM et al., 2007; MOODYSSON et al., 2008). The argument is that tacit knowledge can only be transferred in intense face-to-face interaction and thus relies upon personal interaction in close geographical proximity (ASHEIM and GERTLER, 2005). Know-how, i.e. practical abilities, and know-who, i.e. the capability to effectively use social networks to access additional expertise, are largely dependent on these tacit elements (LUNDVALL and JOHNSON, 1994). Explicit knowledge, on the other hand, can easily be codified and then transferred with the use of written documents, which allows it to transcend greater distances (CASTELLANI and ZANFEI, 2006). This codified knowledge includes knowwhat, i.e. mere factual knowledge, and know-why, i.e. knowledge about methods and scientific principles (JENSEN et al., 2007). Clustering and face-to-face interaction are thus directly linked to tacit knowledge and learning-by-doing and learning-by-interacting (BATHELT et al., 2004).

Whilst this dualism certainly highlights important aspects, recent publications (ASHEIM and GERTLER, 2005; ASHEIM et al., 2007; MOODYSSON et al., 2008) have pointed out that the matter of knowledge transfer is more complex, especially when it is not only considered as a geographical issue, but as the result of various types of proximity. They therefore suggest distinguishing between different knowledge bases, synthetic, analytical and symbolic ones. Although this classification is connected to the differentiation between tacit and explicit knowledge, it is more refined and includes further dimensions.

In the first place, synthetic knowledge bases are characterised by mainly incremental innovation, whereby hands-on solutions emerge from current work and informal coordination with clients and suppliers are crucial. The main perspective is functional. The most important goal is to apply what has been found, and knowledge is considered as a means to achieve new solutions (MOODYSSON et al., 2008). In turn, the dominant forms of learning, i.e. learning by doing, using and interacting, show that tacit knowledge is essential in these knowledge bases (DUNNING et al., 2002). Learning is a recursive trial and 
error process, involving constant feedback-loops and moving experimentally backwards and forwards (MOODYSSON et al., 2008). Activities mainly focus on technological knowledge, which explains why knowhow is the most important form of knowledge in these knowledge bases (MOODYSSON et al., 2008). Faceto-face interaction fosters knowledge exchanges. These are typical characteristics of engineering branches (ASHEIM et al., 2007), i.e. manufacturing and the automobile industry belong to this group. The development of a new engine in the sector of transportation serves as an illustrative example. ${ }^{16}$

The outstanding characteristic of learning in synthetic knowledge bases is personal interaction. It can partly take place through "buzz", i.e. learning happens by just being there, coincidently and without a purpose or a fixed aim in mind (BATHELT et al., 2004). If such learning is to take place, which types of proximity are crucial? First of all, learning occurs in close interaction, based on mutual understanding (cognitive proximity) and the willingness of the involved actors to communicate with each other and to learn from each other (social proximity). This is the case when several engineers as well as the project leader work together at the engine itself. Evidently, both requisites - cognitive and social proximity - are more easily achieved if the actors share norms and values and act in a comparable frame of reference. This refers to the facilitating power of institutional proximity, and as geographical co-locations are usually characterised by common institutional frameworks, geographical proximity is likely to trigger the formerly mentioned three types of proximity - particularly in hands-on learning processes which are physically connected to implementing the engine in the vehicle. In contrast, control-related organisational proximity is not a dominant mechanism of integration as coordination in personal interaction tends to rely on trust and interaction rather than on contracts and control. This is obvious in the initial stage of the project which is driven significantly by individual dedication rather than via pre-established corporate channels. As a result of this, the most important types of proximity in synthetic knowledge bases are cognitive and institutional, whereby both social and geographical proximity prove to be very helpful to enable the inherent vivid and informal communication.

In contrast, analytical knowledge bases proceed in a more planned and intentional fashion. They aim mainly at understanding principles and mechanisms. The most important form of knowledge involved is scientific and thus based on know-why (MOODYSSON et al., 2008). Innovation is radical and results from 
the creation of new knowledge, whereby learning by searching provides the starting point. Innovation is hereby regarded as something which can be planned, and intentional action is taken to move towards innovation step by step. Although this may not result in a linear sequence of activities, the resulting innovation process is very much a formalised one (MOODYSSON et al., 2008). Communication can follow more standardised modes and run along pre-defined channels. Research collaborations focus on the exchange with scientific partners and the emergence of new knowledge is an aim per se and not a means to an end (ASHEIM et al., 2007). A good example for a sector with an analytical knowledge base is drug development in the pharmaceutical industry. At the same time, traditional synthetic sectors incorporate more and more analytical elements. This is, for example, the case in the automobile industry, where the increasingly prominent role of software and IT in automobiles, particularly in connection with new energy and drive technology projects, opens up a whole spectrum of cognitive backgrounds that need to be combined in a single innovation project. In order to draw upon these backgrounds, traditional analytical knowledge bases such as IT and chemistry have to be interlinked with the classical, synthetic knowledge base.

Generally, the deliberate mode of procedure makes it possible to draw upon codified knowledge, to intentionally create accessible and durable knowledge "stores" and to use them independently of geographical, social or institutional proximity. In a pharmaceutical drug development project, for example, chemical formula and study protocols as means of knowledge storage are closely followed by all the participants. Besides, a certain degree of cognitive proximity is indispensable to achieve a correct interpretation of the stored knowledge (NOOTEBOOM, 1999). The participants subdivide tasks according to their professional background and use these professional codes in their communication. Additionally, organisational proximity is necessary to gain access to the stored information, as organisations tend to be careful not to disclose innovative ideas to potential competitors light-heartedly. In the investigated case, communication with outsiders does not take place at all. Whilst cognitive and organisational proximity are hence crucial, social and geographical proximity facilitate the transfer of knowledge and shape the inclusion of members especially in early stages of the project. However, the latter forms turn negligible as soon as the initial, explorative stages have been concluded. ${ }^{17}$ 
In turn, symbolic knowledge bases are related to aesthetic characteristics of products and mostly result in an unexpected recombination of existing knowledge. The involved knowledge is thus explicit. It is inherent in tokens, artefacts and symbols, but at the same time, the art of combining these elements is highly tacit and relies upon subjective and ambiguous factors such as taste and trends. Learning is an interactive process that is based upon an exchange with creative partners, but also occurs through observation and interaction with the rest of the world as part of everyday life. In this context, knowledge does not emerge by applying scientific principles, but through know-who and socialisation in this particular business. Innovation processes are highly emergent and communication is not essentially linked to explanations, understanding and showing, but often resides mainly in a "buzz" of seemingly irrelevant interaction which triggers the process of thinking and may result in new ideas. Face-to-face communication hence represents a critical element. Symbolic knowledge is most obvious in cultural and creative industries (cf. ASHEIM et al., 2007). Nonetheless, just as the other knowledge forms, it is also a cross-sectoral phenomenon, as e.g. in the globalising automobile sector, design has turned into the key competitive factor, and with it, symbolic knowledge assumes a more prominent role in automotive innovation projects.

In this case, at least temporary geographical proximity is absolutely essential. Simultaneously, the subjectivity and ambiguousness involved in this knowledge base underline the importance of trust and, in turn, of social proximity. In many aspects, this trust has to be unconditional, notwithstanding the fact that there is no objective means of controlling whether or not the proposed solution is adequate. In a design project, there is no clearly right or wrong solution; instead, judgement depends more on the feeling for the situation. Institutional proximity can also play a role, as it is necessary to know the values and preferences of the customers as well as the applicable laws. Socio-cultural and legal factors influence taste and routines of the target group. As soon as the product aims at a global market, however, this factor becomes negligible. Products then have to fit into various different institutional frameworks at once. In contrast, organisational proximity is not the focus of attention. Knowledge is deeply rooted within individuals and their past experiences. This makes close control redundant while they exclusively work for one organisation and impossible as soon as they change companies. Brands and reputation are not easy to imitate. Moreover, although a certain degree of cognitive proximity is absolutely essential, its level can remain 
comparably low. There is no clear training involved, and experience and practical issues are far more important than knowing a certain set of rules or procedures. As symbols speak a different language, "talking shop", scientific knowledge and formal training modules are negligible in the learning process. Social proximity hence acts as the main integrating power in symbolic knowledge bases, reinforcing especially the institutional dimension and also as a substitute to cognitive proximity.

Drawing the traits of all three knowledge bases together, synthetic knowledge bases are also referred to as "industrial knowledge bases" (ASHEIM and GERTLER, 2005, p. 294). Here, hands-on activities are dominant, innovation processes focus on applied research and development, and learning emerges from problem-solving in close face-to-face interaction. In analytical knowledge bases, basic research is an end in itself, and many findings are only later translated into applications. Learning here takes place based on the intentional search for new knowledge, concepts and methods, and much of it relies on abstract know-why (MOODYSSON et al., 2008). Symbolic knowledge bases centre on or around informal and emergent learning processes in face-to-face interaction, which avoids any formalisation and is thus not easy to control and protect (ASHEIM et al., 2007).

It could also be shown that each knowledge base has its particular patterns of proximity types. Different forms of knowledge are often complementary (ZANFEI, 2000), but can also act as substitutes. Whilst cognitive proximity is always crucial, a trade-off between institutional and organisational proximity takes place. Social proximity combined with at least temporary geographical co-location also acts as a simplifying mechanism for the overall project. If the project is complex, social proximity creates a greater identification with the project and hence more coherence among the participants. Nonetheless, it is not the crucial means of coordination upon which the projects draw. Besides, the importance of the proximity types varies among the knowledge bases. Dominant in synthetic knowledge bases, institutional proximity encourages a bottom-up process of learning, whereby actors voluntarily and effortlessly get in touch with each other. Social and geographical proximity are thus also important in these learning processes. In analytical knowledge bases, on the other hand, institutional proximity is not as high. This time, the control dimension is more important, which is why common framework conditions are traded for organisational proximity. Belonging to one organisation encourages the sharing of knowledge as a top-down process. 
Learning is here based on official permission or even obligation rather than on macro-level commonalities. This shows that in symbolic knowledge bases, geographical proximity and co-location are decisive, and learning relies highly upon applicability and creative processes. Organisational proximity is not particularly important as much of the involved knowledge evades any attempt to control it. Instead, institutional proximity and especially social proximity based on past interactions can grant a certain level of predictability in the innovation process (cf. also table 1).

Despite its usefulness for obtaining a general idea of the nature of the three knowledge bases, a stiff classification does not grant deeper insights into any particular sector (ASHEIM et al., 2007). For example, the empirical study conducted by MOODYSSON et al. (2008) shows that both synthetic and analytical knowledge bases play a major role in the pharmaceutical sector. The strict divisions between the different knowledge bases, in this manner, blur in real innovation projects. Then, various knowledge bases can overlap and interact in one and the same project. The various types of proximity thereby mirror the involved knowledge bases and help to identify in which aspects a certain knowledge base is crucial. An example is the development of a new drive technology in the automobile sector. Whenever hands-on activities take place and the synthetic knowledge base dominates, these are organised in close geographic proximity and usually carried out by co-workers who know each other (social proximity) and preferably have the same background (institutional proximity). Those parts of the process that are more academic and reflect the analytical knowledge base take place with a close eye on the protection of property rights (control dimension, organisational proximity). Third, the actors involved in symbolic knowledge questions such as design - are granted a high degree of individual freedom, which is meant to trigger creativity. Simultaneously, they have to be familiar with the legal frameworks all over the world to ensure their concepts fit to the prevailing laws (institutional proximity), a process which is facilitated through personal contacts to representatives in the respective countries (social proximity). This brief insight displays that there is a parallelism between various knowledge bases and a dynamic trade-off between multiple forms of proximity. At the same time, it shows how interrelated the various forms of proximity are. Single innovative functions take place in overlapping knowledge bases drawing upon combined sets of proximities. At the same time, process dynamics induce a continuous change of the resulting constellation. The empirical 
identification of knowledge bases hence has to look carefully inside the involved activities as a combination of various facets and factors, not as a homogeneous construction.

Returning to the initially outlined balance between heterogeneity and proximity, we can conclude that the three knowledge bases find different ways towards it. Coping with this challenge is thereby not merely a decision about the degree of proximity, but also involves a trade-off between various types of proximity. Depending on the characteristics of the underlying knowledge base, specific dimensions of proximity vary in regard to their importance. This allows for institutionalising simultaneously proximity and heterogeneity. Whilst one or several types of proximity occur, the distance dominating the remaining dimensions represents heterogeneity and thus provides variety and newness for the project. In this manner, both proximity and heterogeneity can be achieved through partial solutions in that the various dimensions of proximity upon which projects draw are complementary and compensatory to each other. Although a solution is not possible within any of these proximity forms their coexistence enables establishing a solution across several types of proximity in that a lower level of proximity in one dimension can be complemented with a higher level in another type (cf. also BOSCHMA and FRENKEN, 2010). This leads to the conclusion that a purely spatial view on innovation is not adequate and can easily be misleading. In order to understand the dynamics which occur in innovation projects, it is indispensable to look at all five forms of proximity as well as their complementarities and substitution effects. The involved dynamics make it impossible to derive clear spatial patterns for any type of innovation in a theoretical or in an empirical view. Instead, the spatial arrangements of different knowledge bases undergo continuous adaptation processes based on complex shifts and balancing acts.

\section{Conclusions and outlook}

This article has outlined that it is crucial to differentiate between different types of proximity in order to understand learning processes correctly and to disentangle spatial and non-spatial logics of innovation. Following BOSCHMA (2005), it has introduced five types of proximity, namely cognitive, organisational, institutional, social and geographical. The first three of them can be classified as knowledge, control and framework oriented. On the other hand, social and geographical proximity act as auxiliary, reinforcing 
mechanisms. Connected to the different modes of knowledge, the concept helps to explain how learning takes place involving both geographical concentration and supra-regional connections (BATHELT et al., 2004). The simultaneity of various geographical settings reflects a trade-off between multiple types of proximity and triggers a dynamic way of coping with the dichotomy between heterogeneity and proximity. Neither absolute proximity nor complete heterogeneity thereby provides a solution. Proximity in all the proposed categories would be superfluous, whereas no proximity at all would impede collaboration. Based on the trade-off between various forms of proximity, it is possible to find a way of establishing a balance without opting clearly for one of the extremes.

It has been shown that the nature of the underlying knowledge base plays a significant role for the types of proximity necessary to exchange knowledge. First of all, a certain degree of cognitive proximity is crucial in any type of knowledge exchange. Secondly, a trade-off takes place between institutional and organisational proximity. Whereas the former relies upon shared values and laws and encourages learning through informal mechanisms, the latter is based upon formal control and permits the sharing of knowledge. This explains why knowledge exchange based on institutional proximity is dependent upon a higher degree of proximity also in the auxiliary variables, i.e. in social and geographical proximity, as the overall intensity of interaction has to be very high. This is exactly what occurs in synthetic knowledge bases. On the other hand, the transfer of largely codified knowledge as in analytical knowledge bases can take place in an environment involving a generally lower level of proximity, and as a consequence, social and geographical binding mechanisms are not as important. Hence, the difference between the three types of knowledge bases resides in the types of proximity which have to be present as well as the degree of proximity necessary to trigger learning processes.

We can conclude that the three forms of knowledge bases rely on different modes of proximity for learning and innovation, whereby the forms of proximity complement and substitute each other. A closer look at geographical proximity shows that is not at all the crucial mechanism. Rather, many of the arguments in the debate on regional learning in fact refer to the institutional framework. Geographical proximity in a narrower sense acts mainly to facilitate the creation of other forms of proximity, social, organisational and institutional proximity. Only in symbolic knowledge bases does it have an isolated effect. 
At the same time, this does not at all imply the death of geography. On the contrary, it is exactly the facilitating character of spatial proximity which turns geography into a crucial enabler of innovation and learning, whereby the resulting ties are not strictly geographical, but can more precisely be described by recurring upon a wider array of proximity types. Table 1 summarises the relationship between proximity types and knowledge bases.

Table 1: Dimensions of proximity in different knowledge bases

The specific characteristics of analytical, synthetic and symbolic knowledge bases are, as can be seen, closely linked to sector-specific characteristics. Engineering provides a typical case of applied learning-by-doing in synthetic knowledge bases, whereas the pharmaceutical industry is an example of a scientific synthetic knowledge base and the creative industries as well as design projects are based on symbolic knowledge bases. However, no industry is strictly limited to a single type of knowledge base. Instead, different types of proximity are combined in a dynamic way, which is why "it can be suggested that the degree to which (elements of) one mode of knowledge creation dominates is related to the actual stage and activity in the innovation process." (MOODYSSON et al., 2008, p. 1047). This leads to the assumption that companies from any sector cope with the dichotomy between incorporating heterogeneous knowledge and maintaining control through proximity in a dynamic way, which was illustrated in the example of the new drive technology project.

This article has presented a conceptual framework for connecting knowledge bases and proximities. It does not give a full insight into the issue, but opens the door for further research. First, it provides starting points for empirical investigations. A broad study of innovation could help to derive operationalisation mechanisms and to break down the - so far rather abstract - dimensions of proximity into measurable characteristics. Some initial steps have been undertaken to do this, but satisfactory indicators for disentangling the various forms of proximity have not yet been developed (WETERINGS and BOSCHMA, 2009; cf. also BOSCHMA and IAMMARINO, 2009; FRENKEN et al., 2007). Additionally, focussed 
in-depth case studies of innovation projects in particular industries could allow deeper insights, whilst cross-sector comparisons should be conducted to obtain a better understanding of general, inter-sectoral patterns. In order to disentangle spatial and non-spatial dynamics, we also need process-oriented in-depth case studies of whole innovation projects, following them through from their emergence to the market launch. At the same time, important theoretical questions remain open, in particular regarding the underlying processes of communication within and also across knowledge bases. All these topics clearly remain highly relevant. They shed light onto complex intra-organisational and inter-organisational learning and thereby help managers, politicians and scholars not only to understand the underlying spatial and nonspatial processes in a more coherent way, but also to design, organise and frame them accordingly.

\footnotetext{
${ }^{1}$ EDQUIST (2001, p. 219) defines innovations as "new creations of economic significance of either a material or an intangible kind. They may be brand new but are more often new combinations of existing elements."
}

2 Even though the strictly correct opposites would be to use the terms "homogeneity" and "heterogeneity" or "proximity" and "remoteness", this article uses the terms "heterogeneity" and "proximity" as counterparts. The underlying reasons are as follows. The term proximity acts as a link to the debate opened up by BOSCHMA and others (BOSCHMA, 2005) upon which this article explicitly draws. Additionally, proximity implies commonalities which go beyond similarity, but does not suggest sameness or homogeneity. It hence reflects the argumentation line more appropriately than any of the other available terms. Likewise, the term heterogeneity mirrors the requirements in innovation projects better than distance or remoteness would. Variety is here the central idea, not detachedness. In this sense, I hope the reader can forgive pairing these two faintly related concepts - the entailed lack of precision in the pair of opposites is, in my eyes, made up by a more precise transmission of the meaning in the terms.

${ }^{3}$ STORPER (2009) describes context as a "dark matter", as there are presently only few and rather simplistic attempts to explain this phenomenon.

${ }^{4}$ Similarly, GRABHER $(2004,2006)$ stresses the importance of context in reference to projects.

${ }^{5}$ Besides the five-fold break-down of proximity in this article, other authors have suggested approaches with differing foci. Examples include the differentiation between professional, organisational, contextual, technical and further types of distance named by ZELLER (2002) and that between geographical, societal and network embeddedness as proposed by HESS (2004). 
${ }^{6}$ BOSCHMA (2005) uses the term "organisational" not only for those actors who work in the same company, but also if they work in similar organisations and are therefore familiar with the types of rules and modes of coordination that apply. As companies increasingly adopt an international focus and consist of a multitude of intra-organisational linkages (BARTLETT and GHOSHAL, 1990), but also cooperate externally, organisational proximity is even stronger within organisations. It does then not refer to hierarchical or heterarchical forms of organisation, but is, by definition, a means of coordination that embraces all the actors within a single company group. In this article, strong organisational proximity does thus not refer to a common organisational culture etc., but to formally belonging to the same judicial entity.

${ }^{7}$ Although organisational proximity within a single subsidiary is always higher than it can be between several subsidiaries of the same company group, the formal control and property structures within a MNC in both cases guarantee a significantly higher level of organisational proximity in comparison to situations involving external partners.

${ }^{8}$ The importance of institutional frameworks and their impact on organisations have also been discussed in the debates on national innovation systems (NELSON, 1993; TAKAHASHI, 2007; LUNDVALL et al., 2002; EDQUIST 1997) and varieties of capitalism (JOHNSTON, 2005; WHITLEY, 2000). In this manner, institutional proximity also influences the internal manner of coordination and organisation, i.e. organisational proximity.

${ }^{9}$ In the same manner, "institutional thickness" (AMIN and THRIFT, 1995) is not a geographic, but clearly an institutional phenomenon.

${ }^{10}$ Communities of practice and epistemic communities are examples for the power of social proximity. Both rely deeply upon social, tacit and personal forms of interaction. At the same time, social proximity remains a means to an end and does not stand alone. GERTLER (2001, p. 18) describes communities of practice as "informally bound together by shared expertise and a common problem". This definition reflects the importance of cognitive elements (expertise, professional background) in this form of cooperation (cf. also KNOBEN and OERLEMANS, 2006). Furthermore, organisational proximity acts as a pre-selection mechanism which applies before social criteria influence the choice of the actual participants within such a community. Similarly, epistemic communities are deeply knowledge-based, whereby the involved experts share at least cognitive and normative beliefs and values (HAAS, 1992). In short, neither of these forms of community emerges based exclusively on social criteria. 


\begin{abstract}
${ }^{11}$ It must not be forgotten that, just as all the other types of proximity, too much social coherence can be harmful. It results in "strategic friendships", irrational preferences and lock-in into group thinking (GRABHER and IBERT, 2006).

${ }^{12}$ ASHEIM et al. (2007) claim that buzz is not restricted to face-to-face interaction, although it has widely been interpreted as a spatial concept. The underlying claim is hence not that buzz has to take place in geographic proximity, but, in agreement to ASHEIM et al. (2007), that it does most easily and frequently occur in spatially concentrated
\end{abstract} settings.

${ }^{13}$ For a discussion of buzz, spillovers and the resulting "learning regions" cf. also MALMBERG et al., 1996; MASKELL and MALMBERG, 1999; MASKELL and KEBIR, 2006.

14 "In short, 'being there' underpins the joint production, circulation and sharing of knowledge." (GERTLER, 2008).

${ }^{15}$ MORGAN (2004) and others have stressed the continuing importance of geographical aspects of learning. The line of argumentation focuses on relational aspects, i.e. on how geographical proximity fosters the creation of trust and entails commonalities in cultural and legal aspects. These factors are here regarded as social and institutional proximities. At the same time, they are evidently more common and more easily created in geographical proximity, a fact which again underlines the facilitating character of geographical aspects for the other forms of proximity.

${ }^{16}$ The empirical evidence used in this article to illustrate the theoretical argument stems from research the author conducted in the project "Regional Learning in Multinational Companies". Each cited case involves approx. 20 narrative expert interviews in subsidiary, headquarters and the region in question. I would like to thank the Volkswagen Foundation for the financial support of this project and, above all, the interview partners for their time, effort and their disposition for allowing me an in-depth insight into their fascinating innovation projects.

${ }^{17}$ In more complex projects, geographical proximity may turn into a more important auxiliary factor. This can result in temporary co-location, taking the form of meetings or conferences (MASKELL et al., 2006; TORRE, 2008).

\title{
Acknowledgements
}

I would like to thank the participants of the Utrecht International PhD course on Economic Geography 2008 for their comments regarding the very first draft of this paper. I particularly thank Ron Boschma, Bjørn Asheim and Andrés Rodríguez-Pose for their valuable advice regarding earlier versions and their encouragement to have this article published. Finally, the two anonymous reviewers have provided a very constructive feedback which has helped to significantly improve the argument. 


\section{References}

AMBOS B. (2005) Foreign direct investment in industrial research and development: A study of German MNCs, Research Policy 34, 395-410;

AMIN A. (1999) An institutionalist perspective on regional economic development, International Journal of Urban and Regional Research 23, 365-378;

AMIN A. and THRIFT N. (1995) Territoriality in the global political economy, Nordisk Samhällsgeografisk Tidskrift 20, 316;

ANCONA D. and CALDWELL D. (1992) Demography and design: Predictors of new product team performance, Organization Science 3, 321-341;

ASHEIM B. (2000) Industrial districts: The contributions of Marshall and beyond, in CLARK G. L., FELDMAN M. P. and GERTLER M. S. (Eds) The Oxford handbook of economic geography, pp. 413-431. Oxford Univ. Press, Oxford;

ASHEIM B. and COENEN L. (2005) Knowledge bases and regional innovation systems: Comparing Nordic clusters: Regionalization of innovation policy, Research Policy 34, 1173-1190;

ASHEIM B., COENEN L. and VANG J. (2007) Face-to-face, buzz, and knowledge bases: Sociospatial implications for learning, innovation, and innovation policy, Environment and Planning C 25, 655-670;

ASHEIM B. and GERTLER M. S. (2005) The geography of innovation. Regional innovation systems, in FAGERBERG J., MOWERY D. C. and NELSON R. R. (Eds) The Oxford handbook of innovation, pp. 291-317. Oxford Univ. Press, Oxford;

AUDRETSCH D. B. (2000) Corporate form and spatial form, in CLARK G. L., FELDMAN M. P. and GERTLER M. S. (Eds) The Oxford handbook of economic geography, pp. 333-347. Oxford Univ. Press, Oxford;

BARTLETT C. A. and GHOSHAL S. (1990) Managing innovation in the transnational corporation, in BARTLETT C. A., DOZ Y. L. and HEDLUND G. (Eds) Managing the global firm, pp. 215-255. Routledge, London;

BATHELT H. and GLÜCKLER J. (2003) Toward a relational economic geography, Journal of Economic Geography 3, 117144

BATHELT H., MALMBERG A. and MASKELL P. (2004) Clusters and knowledge: Local buzz, global pipelines and the process of knowledge creation, Progress in Human Geography 28, 31-56;

BECHKY B. A. (2003) Sharing meaning across occupational communities: The transformation of understanding on a production floor, Organization Science 14, 312-330; 
BECKER M. C. and KNUDSEN M. P. (2006) Intra and inter-organizational knowledge transfer processes: Identifying the missing links, DRUID working paper 06-32, Copenhagen Business School, Copenhagen;

BECKER-RITTERSPACH F. (2006) Wissenstransfer und -integration im Transnationalen Konzern: Eine soziologische Perspektive, in MENSE-PETERMANN U. and WAGNER G. (Eds) Transnationale Konzerne: Ein neuer Organisationstyp, pp. 153-187. VS Verl. für Sozialwiss., Wiesbaden;

BENDER G. (2004) Heterogenität als Koordinationsproblem: Technikentwicklung in einem Verbundprojekt, in STRÜBING J. (Eds) Kooperation im Niemandsland: Neue Perspektiven auf Zusammenarbeit in Wissenschaft und Technik, pp. 137-161. Leske + Budrich, Opladen;

BLACKLER F., CRUMP N. and MCDONALD S. (2000) Organizing processes in complex activity networks, Organization 7, 277-300;

BOSCHMA R. A. (2005) Proximity and Innovation: A critical assessment, Regional Studies 39, 61-74;

BOSCHMA R. A. and FRENKEN K. (2010) The spatial evolution of innovation networks: a proximity perspective, in BOSCHMA R. A. and MARTIN R. (Eds) The handbook on evolutionary economic geography, pp. 120-135. Elgar, Cheltenham;

BOSCHMA R. A. and IAMMARINO S. (2009) Related variety, trade linkages and regional growth in Italy, Economic Geography 85, 289-311;

BRESCHI S. and CATALINI C. (2007) Tracing the linkages between science and technology: An exploratory analysis of the research networks among scientists and innovator, Paper for the DRUID 25th Celebration Conference, Copenhagen Business School, Copenhagen;

BURT R. S. (1992) Structural holes: The social structure of competition. Harvard Univ. Press., Cambridge;

CALANTONE R. J. and STANKO M. A. (2007) Drivers of oursourced innovation: An exploratory study, Journal of Product Innovation Management 24, 230-241;

CANTWELL J. (2005) Innovation and competitiveness, in FAGERBERG J., MOWERY D. C. and NELSON R. R. (Eds) The Oxford handbook of innovation, pp. 541-567. Oxford Univ. Press, Oxford;

CASTELLANI D. and ZANFEI A. (2006) Multinational firms, innovation and productivity. Elgar, Cheltenham;

CHILD J. and HEAVENS S. J. (2007) The social constitution of organizations and its implications for organizational learning, in DIERKES M., BERTHOIN ANTAL A., CHILD J. and NONAKA I. (Eds) Handbook of organizational learning and knowledge, pp. 308-326. Oxford Univ. Press, Oxford; 
COOKE P. (2001) Regional innovation systems, clusters and the knowledge economy, Industrial and corporate change 10, 945-974;

DOZ Y. L., SANTOS J. and WILLIAMSON P. J. (2001) From global to metanational: How companies win in the knowledge economy. Harvard Business School Press, Boston;

DUNNING J. H. and MUCCHIELLI J.-L. (Eds) (2002) Multinational firms: The global-local dilemma. Routledge, London;

EDQUIST C. (Eds) (1997) Systems of innovation: Technologies, institutions and organizations. Pinter, London;

EDQUIST C. (2001) Innovation policy: A systemic approach, in ARCHIBUGI D. and LUNDVALL B.-Å. (Eds) The globalizing learning economy, pp. 219-237. Oxford Univ. Press, Oxford;

EGELHOFF W. G. (2005) Information-processing theory and the multinational corporation, in GHOSHAL S. and WESTNEY E. D. (Eds) Organization theory and the multinational corporation, 2. ed., pp. 172-197. Palgrave Macmillan, Basingstoke;

ENRIGHT M. J. (1998) Regional clusters and firm strategy, in CHANDLER A. D., HAGSTRÖM P. and SÖLVELL Ö. (Eds) The dynamic firm: The role of technology, strategy, organization and regions, pp. 315-342. Oxford Univ. Press, Oxford;

FRENKEN K., VAN OORT F. and VERBURG T. (2007) Related variety, unrelated variety and regional economic growth, Regional Studies 41, 685-697;

FRITSCH M. and FRANKE G. (2004) Innovation, regional knowledge spillovers and R\&D cooperation, Research Policy 33, 245-255;

GEPPERT M. and CLARK E. (2003) Knowledge and learning in transnational ventures: an actor-centred approach, Management Decision 41, 433-442;

GERTLER M. S. (2001) Best practice? Geography, learning and the institutional limits to strong convergence, Journal of Economic Geography 1, 5-26;

GERTLER M. S. (2003) Tacit knowledge and the economic geography of context, or The undefinable tacitness of being (there), Journal of Economic Geography 3, 75-99;

GERTLER M. S. (2008) Buzz without being there: Communities of practice in context, in AMIN A. and ROBERTS J. (Eds) Communities of Practice: community, economic creativity, and organization, pp. 203-226. Oxford Univ. Press, Oxford;

GERYBADZE A. (2004) Knowledge management, cognitive coherence, and equivocality in distributed innovation processes in MNCs, Management International Review 44, 103-128; 


\footnotetext{
GHOSHAL S. and WESTNEY E. D. (2005) Introduction and overview of the second edition, in GHOSHAL S. and WESTNEY

E. D. (Eds) Organization theory and the multinational corporation, 2. ed., pp. 1-19. Palgrave Macmillan, Basingstoke;
}

GIULIANI E. (2007) The selective nature of knowledge networks in clusters: Evidence from the wine industry, Economic Geography 7, 139-168;

GIULIANI E. (2008) What drives innovative output in emerging clusters: Evidence from the wine industry, SPRU working paper series, 169, Department of Science and Technology Policy Research, University of Sussex, Sussex;

GLÄSER J., MEISTER M., SCHULZ-SCHAEFFER I. and STRÜBING J. (2004) Einleitung: Heterogene Kooperation, in STRÜBING J. (Eds) Kooperation im Niemandsland: Neue Perspektiven auf Zusammenarbeit in Wissenschaft und Technik, pp. 7-24. Leske + Budrich, Opladen;

GRABHER G. (1993) Rediscovering the social in the economics of interfirm relations, in GRABHER G. (Eds) The embedded firm: On the socioeconomics of industrial networks, pp. 1-31. Routledge, London, New York; GRABHER G. (2004) Temporary architectures of learning: Knowledge governance in project ecologies, Organization Studies 25, 1491-1514;

GRABHER G. (2006) Trading routes, bypasses, and risky intersections: Mapping the travels of 'networks' between Economic Sociology and Economic Geography, Progress in Human Geography 30, 1-27;

GRABHER G. and IBERT O. (2006) Bad company? The ambiguity of personal knowledge networks, Journal of Economic Geography 6, 251-271;

GRANT R. M. (1996) Towards a knowledge based theory of the firm, Strategic Management Journal 17, 109-122;

HAAS P. M. (1992) Introduction: Epistemic Communities and International Policy Coordination, International Organization 46, 1-35;

HEIKKINEN M. T. and TÄHTINEN J. (2006) Managed formation process of R\&D networks, International Journal of Innovation Management 10, 271-298;

HESS M. (2004) 'Spatial' relationships? Towards a reconceptualization of embeddedness, Progress in Human Geography 28, 165-186;

HISLOP D. (2003) Knowledge integration processes and the appropriation of innovations, European Journal of Innovation Management 6, 159-172; 
HOERING S., KÜHL S. and SCHULZE-FIELITZ A. (2001) Homogenität und Heterogenität in der

Gruppenzusammensetzung: Eine mikropolitische Studie über Entscheidungsprozesse in der Gruppenarbeit, Arbeit - Zeitschrift für Arbeitsforschung 4, 331-351;

IBARRA H., KILDUFF M. and WENPIN TSAI (2005) Zooming in and out: Connecting individuals and collectivities at the frontiers of organizational network research, Organization Science 16, 359-371;

INKPEN A. C. and TSANG E. W. K. (2005) Social capital, networks and knowledge transfer, Academy of Management Review 30, 146-165;

JENSEN M. B., JOHNSON B., LORENZ E. and LUNDVALL B.-Å. (2007) Forms of knowledge and modes of innovation, Research Policy 36, 680-693;

JOHNSTON S. (2005) Headquarters and subsidiaries in multinational corporations: Strategies, tasks, and coordination. Palgrave Macmillan, Basingstoke;

KILDUFF M. (2005) The reproduction of inertia in multinational corporations, in GHOSHAL S. and WESTNEY E. D. (Eds) Organization theory and the multinational corporation, 2. ed., pp. 241-254. Palgrave Macmillan, Basingstoke; KNOBEN J. and OERLEMANS L. A. (2006) Proximity and inter-organizational collaboration: A literature review, International Journal of Management Reviews 8, 71-89;

LINCOLN Y. S. and GUBA E. G. (1987) Naturalistic inquiry. SAGE, Beverly Hills;

LOVERIDGE R. (2007) Embedding the multinational: Bridging internal and external networks in transitional institutional contexts, in DUNNING J. H. and LIN T.-M. (Eds) Multinational enterprises and emerging challenges of the 21st century, pp. 177-200. Elgar, Cheltenham;

LUNDVALL B.-Å. and JOHNSON B. (1994) The learning economy, Journal of Industry Studies 1, 23-41;

LUNDVALL B.-Å., JOHNSON B., SLOTH E. and ANDERSEN B. D. (2002) National systems of production, innovation and competence building, Research Policy 31, 213-231;

MAGGIONI M. A., NOSVELLI M. and UBERTI T. E. (2007) Space vs. networks in the geography of innovation: A European analysis, Papers in Regional Science 86, 471-493;

MALMBERG A., SÖLVELL Ö. and ZANDER I. (1996) Spatial clustering, local accumulation of knowledge and firm competitiveness, Geografiska Annaler B 78, 85-97;

MARCH J. G. (1991) Exploration and exploitation in organizational learning, Organization Science 2, 71-87;

MARKUSEN A. (1996) Sticky places in slippery space: A typology of industrial districts, Economic Geography 72, 293313; 
MARSH S. J. and STOCK G. N. (2006) Creating dynamic capability: The role of intertemporal integration, knowledge retention, and interpretation, Journal of Product Innovation Management 23, 422-436;

MARSHALL A. (1919) Industry and Trade: A study of industrial technique and business organization, and of their influences on the conditions of various classes and nations. Macmillan, London;

MARSHALL A. (1979 [1890]) Principles of economics: An introductory volume, 8th ed. Macmillan, London;

MASKELL P., BATHELT H. and MALMBERG A. (2006) Building global knowledge pipelines: The role of temporary clusters, European Planning Studies 14, 997-1013;

MASKELL P. and KEBIR L. (2006) What qualifies as a cluster theory?, in ASHEIM B., COOKE P. and MARTIN R. (Eds) Clusters and regional development: Critical reflections and explorations, pp. 30-49. Routledge, London; MASKELL P. and MALMBERG A. (1999) Localised learning and industrial competitiveness, Cambridge Journal of Economics 23, 167-185;

MOODYSSON J., COENEN L. and ASHEIM B. (2008) Explaining spatial patterns of innovation: Analytical and synthetic modes of knowledge creation in the Medicon Valley life-science cluster, Environment and Planning A 40, 10401056;

MORGAN G. (2001) The multinational firm: Organizing across institutional and national divides, in MORGAN G., KRISTENSEN P. H. and WHITLEY R. (Eds) The multinational firm: Organizing across institutional and national divides, pp. 1-24. Oxford Univ. Press, Oxford;

MORGAN K. (2004) The exaggerated death of geography: learning, proximity and territorial innovation systems, Journal of Economic Geography 4, 3-21;

MUDAMBI R., MUDAMBI S. M. and NAVARRA P. (2007) Global innovation in MNCs: The effects of subsidiary selfdetermination and teamwork, Journal of Product Innovation Management 24, 442-455;

NELSON R. R. (1993) National systems of innovation: A comparative analysis. Oxford Univ. Press, Oxford;

NOOTEBOOM B. (1999) Innovation, learning and industrial organisation, Cambridge Journal of Economics 23, 127150;

NOOTEBOOM B., VAN HAVERBEKE W., DUYSTERS G., GILSING V. and VAN DEN OORD A. (2007) Optimal cognitive distance and absorptive capacity, Research Policy 36, 1016-1034;

PAVITT K. (2005) Innovation processes, in FAGERBERG J., MOWERY D. C. and NELSON R. R. (Eds) The Oxford handbook of innovation, pp. 86-114. Oxford Univ. Press, Oxford;

POLANYI M. (1978) Personal knowledge: Towards a post-critical philosophy. repr. Routledge \& Kegan Paul, London; 
POWELL W. W. (1990) Neither market nor hierarchy: Network forms of organization, Research in Organizational Behavior 12, 116-145;

POWELL W. W. and GRODAL S. (2005) Networks of innovators, in FAGERBERG J., MOWERY D. C. and NELSON R. R. (Eds) The Oxford handbook of innovation, pp. 56-85. Oxford Univ. Press, Oxford;

RAMMERT W. (1988) Das Innovationsdilemma: Technikentwicklung im Unternehmen. Westdt. Verl., Opladen;

RODRÍGUEZ-POSE A. and ZADEMACH H.-M. (2006) Industry dynamics in the German merger and acquisitions market, Tijdschrift voor economische en sociale geografie 97, 296-313;

ROTHAERMEL F. T. and DEEDS D. L. (2004) Exploration and exploitation alliances in biotechnology: A system of new product development, Strategic Management Journal 25, 201-221;

SAYER R. A. (1982) Misconceptions of space in social thought, Transactions of the Institute of British Geographers 7, 494-503;

SAYER R. A. (1985) The difference space makes, in GREGORY D. and URRY J. (Eds) Social relations and spatial structures, pp. 49-66. Macmillan, Houndmills;

SAYER R. A. (1992) Method in social science: A realistic approach, 2nd ed. Routledge, London;

SAYER R. A. (2000) Realism and social science. SAGE, London;

STAR S. L. and GRIESEMER J. R. (1989) Institutional ecology, 'translations' and boundary objects: Amateurs and professionals in Berkeley's Museum of Vertebrate Zoology, 1907-39, Social Studies of Science 19, 387-420;

STORPER M. (1997) The regional world: Territorial development in a global economy. Guilford Press, New York;

STORPER M. (2009) Regional context and global trade: Roepke lecture in economic geography, Economic Geography 85, 1-21;

STORPER M. and VENABLES A. J. (2004) Buzz: face-to-face contact and the urban economy, Journal of Economic Geography 4, 351-370;

STRÜBING J. (Eds) (2004) Kooperation im Niemandsland: Neue Perspektiven auf Zusammenarbeit in Wissenschaft und Technik. Leske + Budrich, Opladen;

TAKAHASHI H. (2007) From the internationalization of R\&D to a global R\&D network, in DUNNING J. H. and LIN T.-M. (Eds) Multinational enterprises and emerging challenges of the 21st century, pp. 87-105. Elgar, Cheltenham;

TEECE D. J., PISANO G. and SHUEN A. (1997) Dynamic capabilities and strategic management, Strategic Management Journal 18, 509-533; 
TORRE A. (2008) On the role played by temporary geographical proximity in knowledge transmission, Regional Studies 42, 869-889;

WETERINGS A. and BOSCHMA R. (2009) Does spatial proximity to customers matter for innovative performance? Evidence from the Dutch software sector, Research Policy 38, 746-755;

WHITLEY R. (2000) The institutional structuring of innovation strategies: Business systems, firm types and patterns of technical change in different market economies, Organization Studies 21, 855-886;

WIESENTHAL H. (1995) Konventionelles und unkonventionelles Organisationslernen: Literaturreport und Ergänzungsvorschlag, Zeitschrift für Soziologie 24, 137-155;

WURCHE S. (1994) Vertrauen und ökonomische Rationalität in kooperativen Interorganisationsbeziehungen, in SYDOW J. and WINDELER A. (Eds) Management interorganisationaler Beziehungen: Vertrauen, Kontrolle und Informationstechnik, pp. 142-159. Westdt. Verl., Opladen;

XU D. and SHENKAR O. (2002) Institutional distance and the multinational enterprise, Academy of Management Review 27, 608-618;

YEUNG H. W.-C. (2005) Rethinking relational economic geography, Transactions of the Institute of British Geographers 30, 37-51;

ZANFEI A. (2000) Transnational firms and the changing organisation of innovative activities, Cambridge Journal of Economics 24, 515-542;

ZELLER C. (2002) Project teams as means of restructuring research and development in the pharmaceutical industry, Regional Studies 36, 275-289;

ZHANG J., BADEN-FULLER C. and MANGEMATIN V. (2007) Technological knowledge base, R\&D organization structure and alliance formation: Evidence from the biopharmaceutical industry, Research Policy 36, 515-528. 


\begin{tabular}{|l|l|l|l|}
\hline & Synthetic knowledge & Analytical knowledge & Symbolic knowledge \\
\hline Core idea of innovation & $\begin{array}{l}\text { Emergent application or } \\
\text { recombination of } \\
\text { existing knowledge }\end{array}$ & $\begin{array}{l}\text { Planable creation of new } \\
\text { knowledge }\end{array}$ & $\begin{array}{l}\text { Interactive } \\
\text { recombination of } \\
\text { existing knowledge }\end{array}$ \\
\hline Cognitive proximity & Fundamental & Fundamental & Fundamental (low level) \\
\hline $\begin{array}{l}\text { Organisational } \\
\text { proximity }\end{array}$ & $\begin{array}{l}\text { Subordinate to } \\
\text { institutional proximity }\end{array}$ & $\begin{array}{l}\text { Dominant form of } \\
\text { integration } \\
\text { (learning as top-down } \\
\text { process) }\end{array}$ & Secondary \\
\hline Institutional proximity & $\begin{array}{l}\text { Dominant form of } \\
\text { integration } \\
\text { (learning as bottom-up } \\
\text { process) }\end{array}$ & $\begin{array}{l}\text { Subordinate to } \\
\text { organisational proximity }\end{array}$ & $\begin{array}{l}\text { Important if market is } \\
\text { local }\end{array}$ \\
\hline Geographical proximity & Helpful (auxiliary) & Negligible & Critical \\
\hline
\end{tabular}




\begin{tabular}{|l|l|l|l|}
\hline Social proximity & Helpful (auxiliary) & Negligible & $\begin{array}{l}\text { Critical (social networks } \\
\text { as a substitute to formal } \\
\text { training and cognitive } \\
\text { proximity) }\end{array}$ \\
\hline
\end{tabular}

Table 1: Dimensions of proximity in different knowledge bases (own representation) 